\title{
A abordagem do DNA nos livros de biologia e química do ensino médio: Uma análise crítica
}

Poliana Flávia Maia Ferreira ${ }^{1}$ e Rosária da Silva Justi ${ }^{2}$

${ }^{1}$ Faculdade de Educação; ${ }^{2}$ Departamento de Química

Universidade Federal de Minas Gerais

\section{Resumo}

Neste trabalho fi analisado como ocorre a abordagem do DNA em livros didáticos de biologia e química destinados ao ensino médio. Os aspectos analisados foram a abordagem do tema e os modelos de ensino apresentados pelos autores. A análise mostrou que existem sérios problemas relativos a ambos os aspectos. Como resultado, o ensino do DNA ocorre de forma desvinculada e, muitas vezes, incoerente nas duas disciplinas, não contribuindo para que os alunos entendam e desenvolvam uma visão crítica em relação a temas relativos à engenharia genética bastante enfatizados pela mídia ultimamente. Defendemos que tal ensino ocorra numa perspectiva interdisciplinar, como forma de realmente favorecer um aprendizado significativo dos alunos.

\begin{abstract}
This research analyses the teaching of the DNA as presented by both biology and chemistry textbooks for the medium level. The aspects analysed were the approach proposed and the teaching models presented. It was shown that there are problems concerning with both aspects. As a consequence, the teaching of the DNA occurs in a disconnected and sometimes incoherent way between the two subjects. It does not contribute for students understanding and developing of a critical view about themes related to genetic engineering that has been emphatically published by the media. We advocate that such a teaching occurs from an interdisciplinary perspective so that it could really favour students' meaningful learning.
\end{abstract}

Palavras-chave: DNA, livros didáticos, interdisciplinaridade

Key words: DNA, textbooks, interdisciplinarity

\section{Introdução}

A engenharia genética - área da ciência que tem se desenvolvido rapidamente nos últimos vinte anos tem sido um dos assuntos científicos mais comentados pela mídia em todo o mundo em função de suas importantes aplicações em diversos campos como medicina, química industrial, agricultura, etc. Conseqüentemente, aspectos relacionados com engenharia genética passaram a fazer parte da maioria dos currículos propostos para o ensino de ciências (AAAS, 1990; Brasil, 2000; DFEE, 1995; Ministerio de educación, cultura y desporte, 2001).

Em abril de 2003, celebrou-se 50 anos da descoberta da estrutura da "molécula da vida", o DNA. Essa molécula, que tem sido tão citada pela mídia em artigos que tratam dos avanços alcançados pelo projeto genoma, dos testes de paternidade, da biotecnologia, dos alimentos transgênicos e da clonagem, é um tema que pode gerar um projeto escolar muito rico, capaz de contribuir para a construção de um ensino significativo e que contemple aspectos envolvendo uma interação entre a ciência, a tecnologia e a sociedade.

Estudos realizados na Europa têm evidenciado que estudantes na faixa etária de 13-18 anos apresentam idéias confusas sobre temas na área de genética como, por exemplo, função do DNA e dos genes, transferência genética, projeto genoma, clonagem, etc. (Lewis, Leach, \& Wood-Robinson, 2000; Lewis \& Wood-Robinson, 2000; Martínez-Garcia, Gil-Quílez, \& Osada, 2003). Alguns poucos estudos desenvolvidos no Brasil (como, por exemplo, Ripolli \& Wortmanm, 2002) que investigam idéias de estudantes brasileiros sobre tais temas, bem como 
a prática de professores de química e de biologia aos quais temos tido acesso nos últimos anos têm nos mostrado que tanto esses temas gerais quanto temas mais específicos - como o DNA - são muito mal compreendidos pelos nossos estudantes.

Em função da reconhecida utilização de livros didáticos no ensino, buscamos identificar se o texto trazido por eles seria uma das causas dessa falta de compreensão dos alunos. Para isso analisamos livros didáticos utilizados por professores do ensino médio, tanto de química quanto de biologia. Análises realizadas em livros de biologia no exterior (AAAS, 2002; Martínez-Garcia et al., 2003) concluíram que as abordagens propostas por eles para temas relacionados à engenharia genética não têm contribuído para que os alunos desenvolvam uma compreensão holística do tema.

Divulgados no ano 2000, os Parâmetros Nacionais Curriculares para o Ensino Médio (PCNEM) trazem uma proposta de trabalho para tornar o ensino efetivo, como parte essencial para a formação cidadã e não apenas propedêutico. A interdisciplinaridade aparece nesse documento como uma prerrogativa para a promoção de um aprendizado integrador, com caráter prático e crítico, cujo objetivo é desenvolver competências que possibilitem uma visão de mundo atualizada, a capacidade de compreensão das problemáticas abordadas pelos meios de comunicação e a ação e relação do ser humano com seu meio social e suas tecnologias (BRASIL, 2000).

Entendemos que um ensino com a responsabilidade de formar cidadãos vai muito além do estudo de conteúdos fragmentados, que abordam apenas aspectos teóricos não contextualizados. Esse ensino deve se pautar na visão de que o homem é responsável pela construção e transformação do seu meio e de suas tecnologias, bem como de todo conhecimento científico que é legado da nossa civilização.

No âmbito das propostas dos PCNEM, o DNA é um tema que pode ser amplamente trabalhado através de uma abordagem interdisciplinar, integrando principalmente as áreas de química e biologia, e promovendo uma relação entre progresso científico e avanço tecnológico que, por sua vez, pode imprimir mudanças de hábitos e mentalidade em nossa sociedade.

Apesar de os PCNEM de química não abordarem diretamente o estudo da molécula do DNA, existe uma preocupação com a necessidade da integração dessa disciplina com a biologia ao trabalharem a bioquímica. Segundo tal proposta, o estudo químico das moléculas biológicas deve estar pautado na relação da composição química e sua função nos organismos, buscando tornar o ensino mais próximo da realidade dos alunos.

Para o ensino de biologia, os PCNEM deixam clara a necessidade da descrição do material genético em sua estrutura e composição, vinculada a uma abordagem que permita o desenvolvimento de um posicionamento criterioso relativo ao conjunto das construções e intervenções humanas no mundo, como nos processos de clonagem e alterações genéticas.

"Cabe também, nesse contexto, trabalhar com o aluno no sentido de ele perceber que a estrutura de dupla hélice do DNA é um modelo construído a partir dos conhecimentos sobre sua composição." (BRASIL, 2000)

Ainda segundo os PCNEM de biologia, a descoberta da estrutura do DNA, bem como todo conhecimento científico, deve ser apresentada como um conhecimento humanamente produzido em um dado contexto histórico, como um movimento não linear e, em alguns momentos, contraditório.

Em função de todos os aspectos comentados anteriormente, assim como de nosso interesse em contribuir para que o ensino de ciências, em geral, e de química, em particular, seja mais significativo para os alunos, decidimos analisar como a abordagem do DNA é proposta em livros de biologia e de química destinados ao nível médio de escolaridade no Brasil. As questões que nortearam essa pesquisa foram:

- Como as abordagens utilizadas por livros didáticos de química e biologia para o estudo do DNA no nível médio contribuem para o aprendizado significativo desse tema? 
- Como os principais modelos de ensino apresentados em livros didáticos de química e biologia podem contribuir para o aprendizado de aspectos sobre o DNA?

Dessa maneira, a análise dos livros visa enfocar as abordagens e os modelos de ensino ${ }^{1}$ utilizados pelos mesmos, permitindo-nos fazer um levantamento dos principais pontos que podem estar contribuindo para as dificuldades apresentadas na aprendizagem do DNA e, conseqüentemente, dos temas a ele relacionados.

\section{Metodologia}

\section{Amostra}

A seleção dos livros foi realizada através de consulta verbal feita com professores de química e biologia do ensino médio, tanto da rede particular quanto da rede pública de Belo Horizonte. Alguns dos livros apontados como mais utilizados, assim como o código que lhes foi atribuído neste trabalho, encontram-se listados na tabela 1.

\begin{tabular}{|c|c|}
\hline Código & Livro \\
\hline B1 & Lopes, S. (1998). BIO, v. 1, $4^{\text {a }}$ edição. São Paulo: Saraiva. \\
\hline $\mathrm{B} 2$ & Soares, J.L. (1998). Biologia no terceiro milênio, v. 1, 1ª edição. São Paulo: Scipione. \\
\hline B3 & Amabis, J.M. e Martho, G.R. (2001). Conceitos de biologia, v. 1, $1^{\text {a }}$ edição. São Paulo: Moderna. \\
\hline B4 & Uzunian, A. e Birner, E. (2004). Biologia, v. único, 2a edição. São Paulo: Harbra. \\
\hline Q1 & Reis, M. (2001). Completamente Química, v. 3, 1ª edição. São Paulo: FTD. \\
\hline Q2 & Peruzzo, F.M. e Canto, E.L. (2003). Química no Cotidiano, v.3, $3^{\text {a }}$ edição. São Paulo: Moderna. \\
\hline Q3 & Lembo, A. (2003). Química: Realidade e Contexto, v.3, 1ª edição. São Paulo: Ática. \\
\hline
\end{tabular}

Tabela 1. Livros didáticos utilizados na análise.

Em todos os livros, foram analisados textos e atividades que se referiam ao estudo do DNA, seja no estudo das moléculas bioquímicas, seja no processo de divisão nuclear das células (no caso dos livros de biologia).

\section{Critérios de Análise}

Os critérios utilizados na análise dos livros relacionaram-se com cada uma das questões de pesquisa e foram concebidos como sub-questões relativas à abordagem e aos modelos de ensino. Tais questões são apresentadas na tabela 2 .

\begin{tabular}{|c|l|}
\hline Tema da questão de pesquisa & \multicolumn{1}{|c|}{ Sub-questões utilizadas na análise } \\
\hline Abordagem do DNA & $\begin{array}{l}\text { Quais os pré-requisitos seriam necessários para a abordagem (de acordo com } \\
\text { a complexidade com a qual é apresentado)? }\end{array}$ \\
\cline { 2 - 3 } & $\begin{array}{l}\text { Os alunos, naquele momento do aprendizado, já teriam estudado os } \\
\text { conteúdos considerados pré-requisitos? }\end{array}$ \\
\cline { 2 - 3 } & Os livros analisados apresentam alguma contextualização histórica? \\
\cline { 2 - 3 } & $\begin{array}{l}\text { Como essa contextualização pode contribuir para que o estudante } \\
\text { compreenda a construção e progresso da produção do conhecimento } \\
\text { científico? }\end{array}$ \\
\hline
\end{tabular}

\footnotetext{
${ }^{1}$ Neste trabalho, modelos de ensino são considerados como representações criadas com o objetivo específico de ajudar alunos a entenderem algum aspecto do conteúdo curricular (Gilbert \& Boulter, 1995).
} 


\begin{tabular}{|l|l|}
\hline \multirow{3}{*}{ Modelos de ensino } & $\begin{array}{l}\text { Como a abordagem trazida pelos livros auxilia na compreensão da função do } \\
\text { DNA e da relação desse com os processos auais retratados pela mídia } \\
\text { (clonagem, teste de DNA, alterações genéticas...)? }\end{array}$ \\
\hline & $\begin{array}{l}\text { Os modelos e os conceitos apresentados estão de acordo com aqueles aceitos } \\
\text { cientificamente? }\end{array}$ \\
\cline { 2 - 3 } & $\begin{array}{l}\text { Há um consenso entre os modelos apresentados pelos livros de química e de } \\
\text { biologia? }\end{array}$ \\
\cline { 2 - 3 } & $\begin{array}{l}\text { Como os modelos apresentados contribuem para a compreensão da estrutura } \\
\text { do DNA? }\end{array}$ \\
\cline { 2 - 3 } & $\begin{array}{l}\text { Em que extensão as particularidades relativas às duas disciplinas contribuem } \\
\text { para a compreensão de um modelo único do DNA? }\end{array}$ \\
\cline { 2 - 3 } & $\begin{array}{l}\text { Tais modelos apresentam pontos que podem gerar ou reforçar concepções } \\
\text { alternativas transportadas interdisciplinarmente? }\end{array}$ \\
\hline
\end{tabular}

Tabela 2. Sub-questões que orientaram a análise dos livros didáticos.

\section{Resultados e Discussão}

\section{Consideração Prévia}

A seleção dos textos a serem analisados evidenciou que, nos livros didáticos de ambas disciplinas, o estudo do DNA se resume, em geral, a uma abordagem bastante breve acompanhada de algum modelo que represente a estrutura dessa molécula. É interessante ressaltar que no livro Q3 esse tema foi abordado apenas como texto auxiliar no capítulo intitulado "As moléculas da vida".

\section{Aspectos relativos à abordagem dos livros}

\section{Momento da abordagem do tema no ensino e pré-requisitos necessários}

O estudo do DNA é realizado em momentos bastante diferentes se comparamos os ensinos nas disciplinas química e biologia. Enquanto esse estudo é realizado na biologia, de modo geral, já na primeira série do ensino médio, a química o traz como um conteúdo da terceira série desse ensino.

As divergências do ensino nas duas disciplinas se iniciam pela organização dos conteúdos. Em geral, os estudos de biologia são iniciados, na primeira série do Ensino Médio, abordando os vários níveis de organização de um ser vivo, o que inclui a sua composição química (bioquímica). Enquanto is so, os estudos de química se iniciam, nessa mesma série, no nível macroscópico (discutindo as propriedades dos materiais), para só então partir para o estudo dos átomos, das moléculas, ligações...

Assim, o estudo das moléculas orgânicas na biologia se inicia antes mesmo de o aluno ter o conhecimento relativo aos átomos, ligações e mesmo às moléculas, conteúdos que se mostram necessários para o entendimento desse estudo inicial da biologia, pelo menos com a complexidade que é abordado.

Na química, em contrapartida, o estudo do DNA só é realizado na terceira série do ensino médio em virtude de o conteúdo de química orgânica ser considerado um pré-requisito necessário para a compreensão da estrutura do DNA.

Dessa forma, o estudo do DNA aparece nas duas disciplinas em momentos bastante distantes, trabalhados com enfoques totalmente diferentes e sem o estabelecimento de um vínculo entre os conteúdos de uma e outra disciplina.

\section{Contextualização histórica}


Em relação a esse aspecto, observou-se que um dos livros didáticos, B2, não apresentou sequer uma citação da história ou período histórico em que ocorreu a descoberta da estrutura do DNA. Os demais livros analisados o fizeram de maneira bastante breve e de forma linear.

Em nenhum momento a história dessa descoberta científica se referiu às várias pesquisas realizadas sobre o assunto nessa época, como os estudos sobre DNA realizados por Rosalind Franklin e Maurice Wilkins através de difração de raios X (Thieman, 2003). E, ainda, nenhuma referência foi feita aos vários cientistas, como Linus Pauling e John Randall, por exemplo, que estiveram envolvidos nesse estudo, aos modelos anteriores ao modelo de dupla-hélice, ou a qualquer fato referente aos erros e contradições existentes nesse processo do desenvolvimento do conhecimento científico. A história é contada a partir do acerto e como fruto da pesquisa apenas dos cientistas James Dewey Watson e Francis Harry Crick. O texto abaixo foi selecionado para exemplificar como essa contextualização foi apresentada nos livros B1, B3, B4 e Q1:

“O modelo da estrutura molecular do DNA foi proposto em 1953, por Watson \& Crick, e é aceito até hoje.” (livro B1, p.203)

Ainda que de maneira breve e sem apresentar a merecida contextualização dessa descoberta, a contextualização dos livros Q2 e Q3 ainda se mostrou melhor que a dos outros citados anteriormente. Neles, além da proposição do modelo de dupla-hélice por Watson e Crick em 1953, é narrada a descoberta da existência do ácido nucléico - e o porquê desse nome.

Contribuições para a compreensão da função do DNA e da relação desse com os processos atuais retratados pela mídia

Em relação à função do DNA nos organismos, observamos que os livros de biologia, apesar de citarem que o DNA "é a estrutura responsável pelo controle das funções da célula" (B4, p. 42), não detalham esse processo no sentido de explicar como ele ocorre. Isso porque não é apresentado que esse controle é feito por ativação e receptores que desencadeiam uma série de reações químicas - nas quais ocorrem quebras e formações de ligações químicas específicas - que levam à produção de proteínas. Além disso,esses livros trabalham o DNA independente do estudo de genética e hereditariedade. Os livros de química, por sua vez, contemplam aspectos restritos ao estudo da estrutura do DNA em detrimento à sua função.

Sobre aspectos da ciência moderna, amplamente divulgados pela mídia na atualidade, foram apresentados apenas alguns textos auxiliares que, entretanto, não trazem uma abordagem significativa do DNA. Esses textos, encontrados nos livros de biologia apenas na parte do estudo de genética, apresentam como temas principais o projeto genoma e alguns aspectos simples de engenharia genética. Tais textos trabalham a genética e a manipulação do DNA como se fossem independentes de sua composição e estrutura e, ainda, sem uma discussão ética sobre a utilização de tais processos na sociedade (Lewis \& Wood-Robinson, 2000). Essa discussão não é retomada nem mesmo nos exercícios ao final dos capítulos.

Nesse momento fica evidente a fragmentação do ensino, uma vez que inicialmente se estuda a composição e estrutura do DNA e, em um segundo momento, quando se estuda genética ou mesmo divisão celular, não é feita nenhuma relação direta com esse primeiro estudo.

Dada a falta de abordagem ou a abordagem superficial em relação a questões como clonagem, engenharia genética, alimentos transgênicos, testes de paternidade, é possível observar que esses livros poderiam não favorecer a construção de um conhecimento que propicie a aprendizagem conteúdos relevantes para a formação de uma postura crítica, capaz de dialogar com o conhecimento científico e avaliar questões éticas relativas ao seu emprego - como defendido nos PCNEM. 


\section{Aspectos relativos aos modelos de ensino}

Coerência com os modelos científicos

Ao analisarmos os modelos de DNA propostos pelos livros, foi possível observar a ocorrência de alguns desses que estavam em desacordo com aspectos propostos pelos modelos científicos. Foram observados erros bastante explícitos como, por exemplo, carbono realizando três ligações ao invés de quatro (figura 1) ou, ainda, os açúcares externos aos "corrimões" da dupla hélice ao invés de constituindo os mesmos (figura 2).

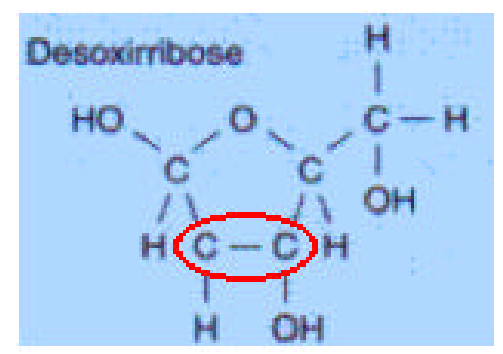

Figura 1: Estrutura química da desoxirribose, livro B3, p. 52. (destaque nosso)

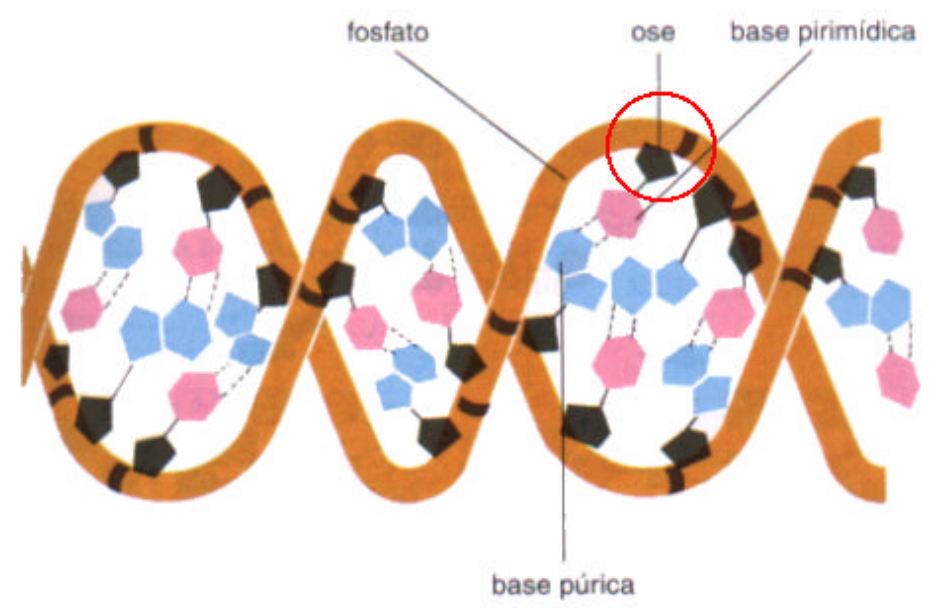

Figura 2: Representação da dupla-hélice, livro B2, p. 105. (destaque nosso)

Outros erros relativos à conformação da estrutura também foram observados, como a estereoquímica incorreta da estrutura do DNA ou de suas partes constituintes (figuras 2 e 3), o giro da hélice no sentido antihorário, a desproporção na representação do passo da hélice (figura 2) ou, ainda, a representação de diferentes passos para a mesma hélice (figura 2). Apesar de julgarmos que tais aspectos podem não ser considerados tão relevantes no comprometimento do entendimento dos alunos em relação ao tema em geral, isso evidencia a falta de coerência dos livros com os modelos científicos. 


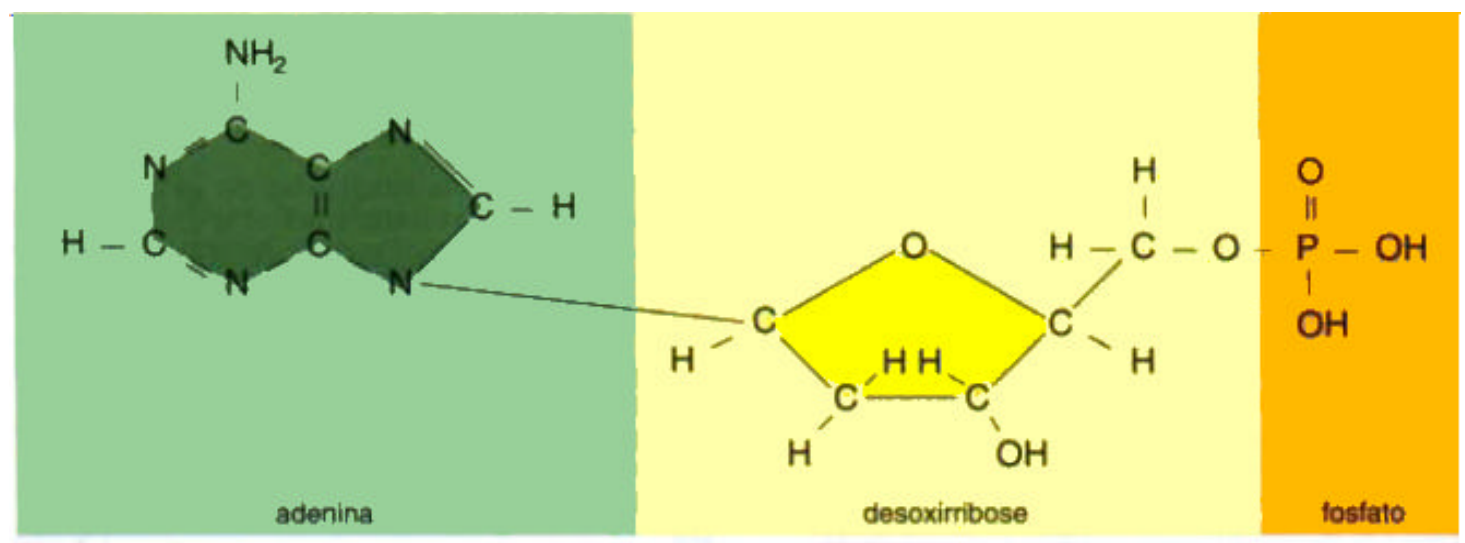

Figura 3: Representação do nucleotídeo, livro B2, p. 104.

Dentre os livros analisados, essas incoerências com o modelo científico aceito para a estrutura do DNA apareceram somente nos de biologia. Acreditamos que apesar de o detalhamento químico dessa estrutura não ser o foco principal de estudo na biologia, ele deve ser corretamente representado de forma a promover uma compreensão para o entendimento do tema, mesmo que os modelos apresentados sejam simplificados. Caso contrário, esses modelos podem contribuir para um entendimento equivocado, que pode ultrapassar as barreiras disciplinares e prejudicar a compreensão de outras estruturas na química.

Consenso entre modelos apresentados em diferentes livros

Vários foram os modelos apresentados pelos livros analisados. Observou-se, no entanto, que os livros de biologia apresentavam modelos bastante diferentes entre si, e esses ainda mais diferentes em relação aos modelos apresentados pelos livros de química.

Enquanto nos livros de biologia prevalecem modelos demasiadamente simplificados para a representação do DNA - muitas vezes utilizando formas geométricas em lugar das estruturas químicas e encaixes de formas geométricas no lugar de interações (figura 4) -, os livros de química apresentaram estruturas com todos os átomos, ligações e interações relativas àquela estrutura (figura 5) sem, no entanto, dar a merecida atenção à conformação em dupla-hélice e sua disposição espacial. 


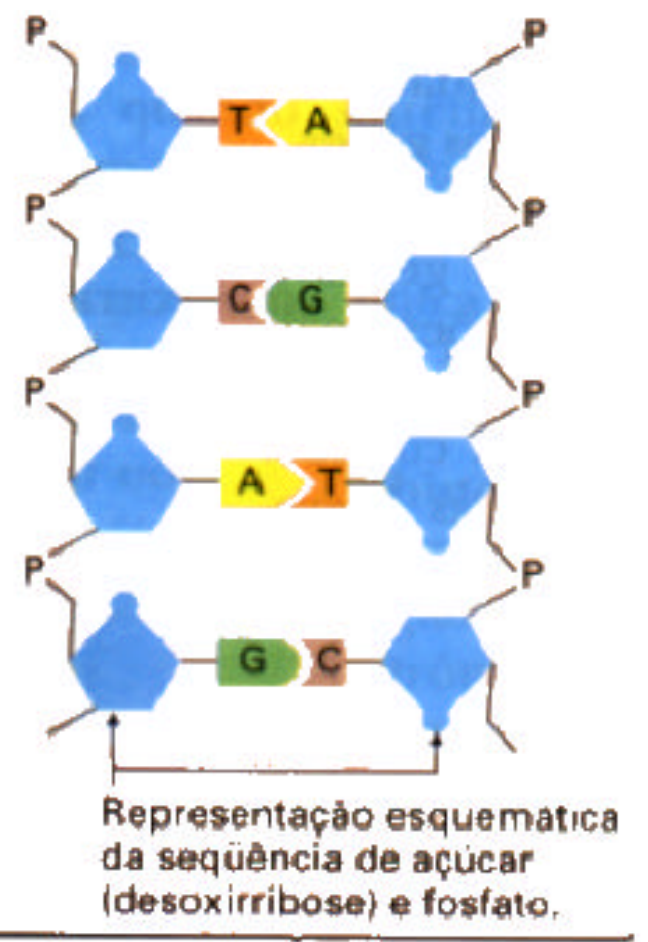

Representaçáo esquematica das duas cadeias complementares de nucleotideos definidas ao lado.

Figura 4: Modelo para a estrutura do DNA, livro B1 , p. 204.

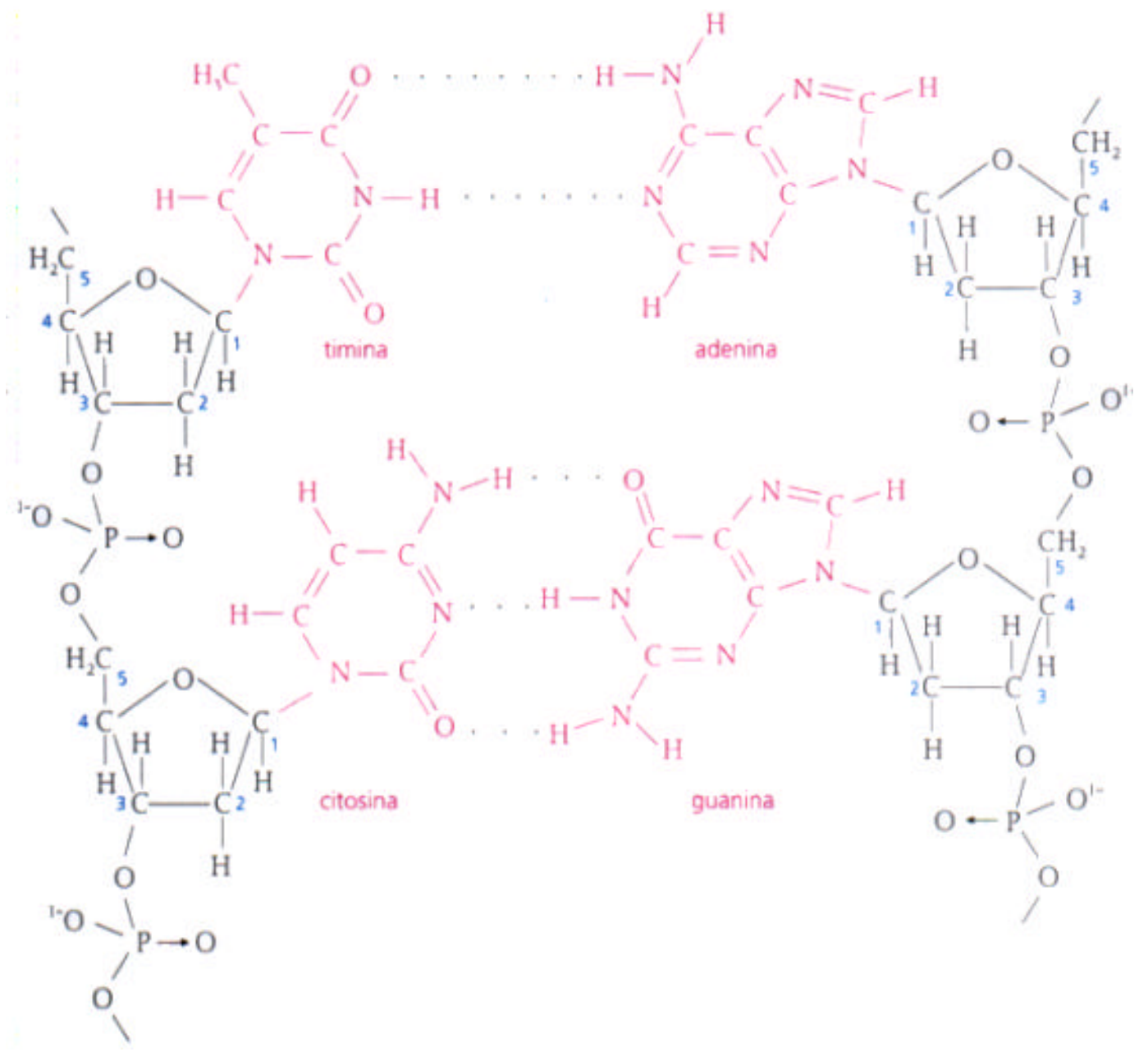


Figura 5: Estrutura do DNA e ligações de hidrogênio entre as bases nitrogenadas, livro Q1, p. 385.

Observou-se, ainda, que um mesmo livro utiliza modelos diferentes para a representação das partes da estrutura ou da estrutura em si, sem manter sequer um padrão de cores, o que pode prejudicar o estabelecimento de uma relação entre os modelos ou mesmo a identificação de determinadas estruturas em um outro modelo (figuras 2 e 3).

Contribuições para a compreensão da constituição e disposição da estrutura do DNA

Aspectos como a falta de coerência dos modelos apresentados para a estrutura do DNA com os modelos cientificamente aceitos e a extrema simplificação das estruturas acabam por prejudicar a compreensão da estrutura do DNA, no que se refere à sua composição e disposição.

Estruturas representadas como figuras geométricas tendem a impossibilitar que o aluno compreenda a estrutura do DNA como uma estrutura química, o que pode prejudicar o estabelecimento de uma relação entre duplicação do DNA e interações e ligações químicas. O DNA, da forma como foi apresentado, aparece muito distante de sua função e aplicação. Por incrível que pareça, o tema no qual o DNA é mais aplicado - a genética -, aparece totalmente desvinculado do estudo do mesmo.

Sobre a estrutura do DNA, um aspecto relevante nessa discussão é a impossibilidade de sua visualização como uma dupla-hélice uma vez que é um modelo em três dimensões. Para a compreensão da disposição da estrutura, o DNA é apresentado como uma escada, em que os grupos fosfato e os açúcares formam os corrimões e as bases nitrogenadas os degraus. Essa representação, no entanto, só ficou clara no livro B4 (figura 6); os demais livros apenas citaram que a disposição da estrutura do DNA pode ser comparada a uma escada.

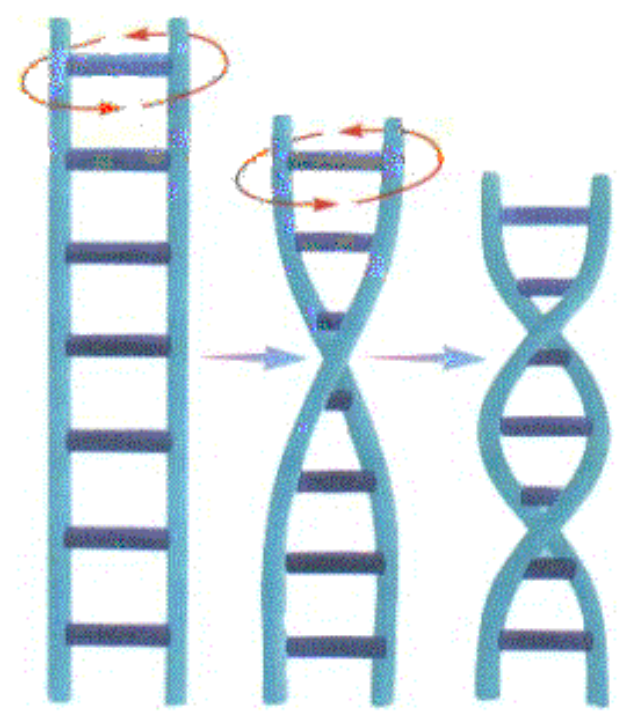

Figura 6: Representação da estrutura do DNA disposto como uma escada, livro B4, p. 127.

\section{Modelos de ensino e concepções alternativas}

Não apenas os erros apresentados pelos modelos podem contribuir para um entendimento equivocado do assunto, mas alguns modelos podem trazer elementos que provoquem a construção ou reforço de concepções alternativas dos alunos.

Um modelo bastante encontrado nos livros de biologia é a substituição de estruturas químicas por representações geométricas (figuras 2,4 e 7). Reconhecemos a validade da utilização dessa representação para o entendimento da conformação do DNA, prática utilizada pelos próprios cientistas Watson e Crick durante a proposição da estrutura do mesmo. Entretanto, acreditamos que se essa simplificação não for acompanhada de uma 
devida abordagem da estrutura dessa molécula ela pode prejudicar a compreensão do DNA como uma substância química. Isso impossibilitaria, por exemplo, a compreensão das ligações de hidrogênio, por não apresentar os átomos que participam dessa interação.

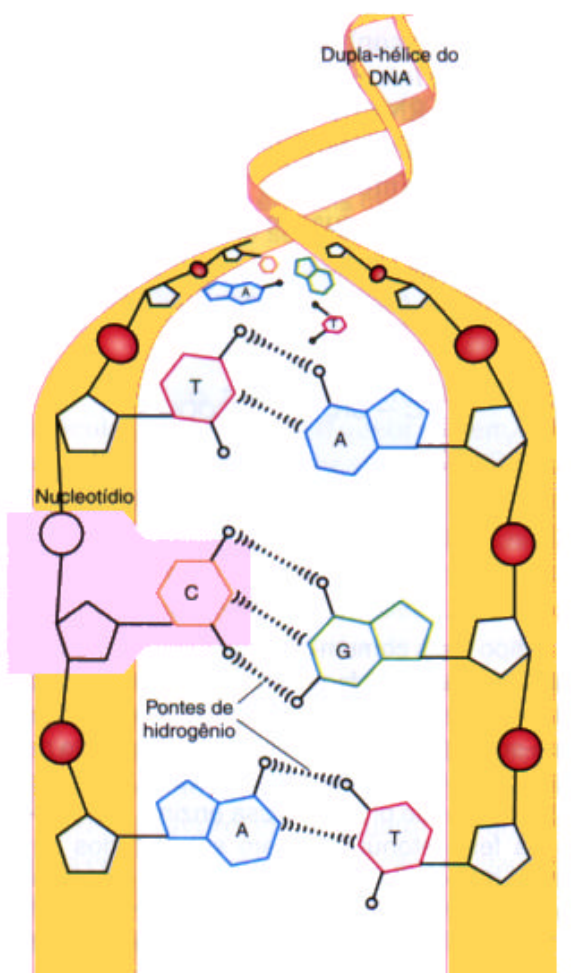

Figura 7: Representação da dupla-hélice do DNA e das ligações de hidrogênio, livro B3, p. 52.

Um modelo que pode gerar uma concepção alternativa peculiar é o apresentado nas figuras 2 e 7. Esse modelo transmite a idéia que os "corrimões" da dupla fita de DNA contêm os grupos fosfato e ribose, e não que são formados por esses.

Preenchimento interno às estruturas (figuras 3 e 8) é um outro aspecto apresentado em vários modelos que pode gerar a concepção de que há matéria na região interna a essas estruturas, prejudicando a compreensão de estruturas químicas.
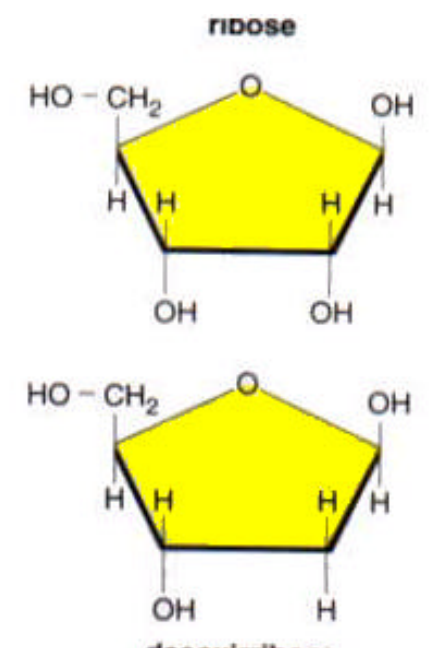

Figura 8: Estruturas da ribose e desoxirribose, livro B2, p. 105. 


\section{Conclusões}

O DNA, molécula de tamanha importância biológica, se mostrou, através da análise realizada, pouco e mal explorado nos livros didáticos do Ensino Médio. Foi possível observar uma fragmentação inadequada de conteúdos entre a química e a biologia, de maneira que cada disciplina contempla apenas certos aspectos do tema, não permitindo uma compreensão geral do mesmo.

Infelizmente, ao contrário de um trabalho rico que poderia ser desenvolvido a partir do estudo do DNA, o que se observa é uma separação do estudo desse tema entre a biologia e a química, o que leva a uma falta de coesão entre essas duas áreas e sem contemplar os demais aspectos relacionados ao mesmo.

É clara a preocupação que os autores de livros de biologia têm em tratar da função do DNA em detrimento da sua estrutura e características químicas. Aspectos como estereoquímica, modelos de ligações e interações e composição química da molécula, são ignorados pelos livros de biologia analisados. Assim, a compreensão dos alunos sobre os textos de engenharia genética apresentados fica limitada, como conseqüência da abordagem pobre dada à estrutura do DNA e sua manipulação. Tal aspecto também foi destacado em uma análise feita em livros de biologia espanhóis (Martínez-Garcia et al., 2003).

A análise da abordagem promovida pela química permitiu observar que essa disciplina utiliza esse tema apenas como pretexto (e não contexto) para trabalhar classificação e conformação das estruturas químicas, não enfatizando a importância do DNA como molécula biológica.

Assim, se a seqüência de conteúdos apresentada pelo livro didático for o único recurso utilizado pelo professor, o ensino atualmente promovido acaba por gerar dois conceitos sobre esse mesmo tema, sendo estudado o "DNA da química" e o "DNA da biologia" e, aquém desses dois, fica o "DNA da mídia" (Maia, 2004). Ao final desse ensino, a visão do aluno pode ser confusa, cabendo a ele juntar as peças desse quebra-cabeça para, só então, compreender que o DNA estudado na biologia é o mesmo da química.

Uma análise mais geral permitiu apontar a abordagem do DNA nos livros analisados como superficial e ineficiente no que toca à sua contribuição para a construção de um conhecimento significativo.

Em qualquer momento, nenhum dos livros apresentou uma contextualização pertinente ao tema, seja na parte histórica, tecnológica ou social. Citações (e rõo contextualizações) históricas foram mais freqüentemente observadas, entretanto, nada que contribuísse para o aluno compreender o desenvolvimento do conhecimento científico e a importância dele no contexto social.

A abordagem limitada ou a ênfase na abordagem do tema e a falta de contextualização histórica não são os únicos fatores que prejudicam o processo de ensino-aprendizagem. É possível citar, ainda, problemas relativos aos modelos de ensino apresentados pelos autores como um dos principais fatores responsáveis pela construção de conceitos equivocados.

Os modelos de ensino foram mais freqüentemente encontrados como ilustrações e esquemas, por vezes diferentes em química e biologia. Outras vezes, tais modelos se mostraram muito simplificados, e mesmo errados, dificultando, assim, a interligação dos conteúdos vistos nessas duas disciplinas, o que pode prejudicar o processo de ensino-aprendizagem.

Defendemos que a abordagem do tema DNA deva passar por uma série de redirecionamentos que seriam bastante relevantes para a educação científica. Seria necessário, ainda, suprir a carência de propostas interdisciplinares para o aprendizado - o que tem contribuído para uma educação científica excessivamente compartimentada -, fazendo uso de instrumentos que poderiam favorecer naturalmente a interdisciplinaridade, como os modelos moleculares, por exemplo (Brasil, 2000).

Apesar de toda a crítica apresentada, não é desejado acabar com a disciplinaridade existente no ensino, mesmo porque ela é importante para a contemplação de competências e habilidades específicas das disciplinas (Lopes, 1999). Entretanto, o entendimento do DNA requer a interação entre os conhecimentos químicos e biológicos, e desses com o contexto social e tecnológico em que está inserido. 
Não pretendemos que o DNA seja estudado com toda a sua complexidade em uma primeira abordagem, ou em qualquer momento do ensino médio. Não defendemos, por exemplo, que no estudo do DNA na química e na biologia do ensino médio sejam utilizados os modelos científicos mais completos e complexos possíveis. Os modelos utilizados no ensino são válidos para representar e simplificar o estudo de uma parte específica do assunto, auxiliando na compreensão do que é pertinente naquele momento. Entretanto, a proposta de uma abordagem interdisciplinar diminui a possibilidade de concepções equivocadas transportadas de uma disciplina para outra, ou mesmo a falta de ligação entre os conteúdos estudados nas duas disciplinas entre si e com o universo dos alunos.

Esse trabalho permitiu observarmos que os livros não contemplam os aspectos sugeridos pelos PCNEM, principalmente no que se refere à interdisciplinaridade. Entretanto, cabe a nós questionarmos o quanto os PCNEM são interdisciplinares entre si, uma vez que não se observa um diálogo efetivo entre as disciplinas na formulação dessa proposta. Mesmo no detalhamento de temas trazido pelos PCN+ (Brasil, 2002) não se observa uma proposta que interligue a química e a biologia. Acreditamos que isso seria desejável no sentido de efetivamente oferecer uma orientação para autores de livros e para professores a fim de que adotassem essa proposta contemplando aspectos nela tão enfaticamente defendidos como, por exemplo, a interdisciplinaridade.

\section{Agradecimentos}

As autoras agradecem à professora doutora Carmem Maria De Caro Martins, pelas sugestões que muito contribuíram para a conclusão desse texto.

\section{Referências Bibliográficas}

AAAS (American Association for the Advancement of Science). (1990). Science for All Americans - Project 2061. Oxford and New York: Oxford University Press.

AAAS (American Association for the Advancement of Science). (2002). AAAS Project 2001 Biology Textbooks Evaluation. Disponível em http://www.project2061.org/research/textbook/hsbio/default.htm. (acessado em 23/04/2004).

Brasil (2000). Parâmetros Curriculares Nacionais (Ensino Médio), Parte III - Ciências da Natureza, Matemática e suas Tecnologias. Brasília: Ministério da Educação e Cultura.

Brasil (2002). PCN+: Orientações educacionais complementares aos Parâmetros Curriculares Nacionais, Ciências da Natureza, Matemática e suas Tecnologias. Brasília: Ministério da Educação e Cultura.

DFEE (Department for Education and Employment) (1995). Science in the National Curriculum. London: DFE and The Welsh Office.

Gilbert, J. \& Boulter, C. (1995). Stretching models too far. Paper presented at the Annual Conference of the American Educational Research Association, San Francisco, 18-22 April.

Lewis, J., Leach, J., \& Wood-Robinson, C. (2000). All in the genes? - Young people's understanding of the nature of genes. Journal of Biological Education, 34(1), 74-79.

Lewis, J., \& Wood-Robinson, C. (2000). Genes, chromosomes, cell division and inheritance - do students see any relationship?, International Journal of Science Education, 22(2), 177-195.

Lopes, A. R. C. (1999). Conhecimento escolar: ciência e cotidiano. Rio de Janeiro: Editora da Universidade Federal do Rio de Janeiro.

Maia, P.F. (2004). 50 anos de (des)conhecimento do DNA: Uma análise da abordagem do DNA em livros de biologia e química do ensino médio. Monografia de Licenciatura. Belo Horizonte: Departamento de Química da UFMG. 
Martínez-Gracia, M.V., Gil-Quílez, M.J., \& Osada, J. (2003). Genetic engineering: a matter that requires further refinement in Spanish secondary school textbooks. International Journal of Science Education, 25(9), 11471168.

Ministerio de educacíón, cultura Y deporte (2001). Real decreto 3473/2000 por el que se estabelecen las enseñanzas mínimas correspondientes a la Educación Secundaria Obligatoria. Boletín Oficial Estado, 14, $1810-1858$.

Ripolli, D. \& Wortmanm, M.L.C. (2002). A genética e a biotecnologia na mídia impressa: o que a educação tem a ver com isso?. Artigo apresentado no VIII Encontro Perspectivas do Ensino de Biologia, São Paulo, 20-22 de fevereiro.

Thieman, O.H. (2003). A descoberta da estrutura do DNA: de Mendel a Watson e Crick. Química Nova na Escola, 17, 13-19. 